\title{
APLIKASI METODE QUALITY FUNCTION DEPLOYMENT ( QFD ) UNTUK MENINGKATKAN KUALITAS PELAYANAN PUBLIK DI RSUD BUNDER KABUPATEN GRESIK
}

\author{
Pregiwati Pusporini \\ Program Studi Teknik Industri - Fakultas Teknik \\ Universitas Muhammadiyah Gresik
}

\begin{abstract}
ABSTRAKSI
Rumah Sakit merupakan salah satu sistem produksi yang tidak menghasilkan produk berwujud ( tangible ) tetapi keluarannya berupa jasa ( layanan ). Masukan untuk suatu system produksi jasa seperti Rumah sakit adalah konsumen itu sendiri. Proses produksi yang mengubah masukan menjadi keluaran terdiri dari tenaga kerja, teknologi, informasi dan sebagainya. Dalam sistem jasa Rumah sakit yang menjadi dasar dan ujung tombak pelayanannya kepada masyarakat adalah layanan pelanggan / customer service.

Pada dasarnya Rumah Sakit adalah suatu organisasi non profit dimana dalam menjalankan usahanya lebih mengutamakan kepentingan masyarakat dan tidak sepenuhnya mencari laba ( keuntungan ). Sebagai organisasi non profit, kegiatan Rumah Sakit tidak berbeda dengan kegiatan organisasi yang mencari laba.

Rumah Sakit dituntut untuk memberi pelayanan yang bermutu sehingga dapat memuaskan konsumennya. Kepuasan konsumen didefinisikan sebagai sikap konsumen secara keseluruhan yang memandang dengan baik suatu barang atau jasa setelah memperoleh dan menggunakannya. Jadi kepuasan konsumen adalah penilaian setelah melakukan konsumsi.

Dengan mengaplikasikan metode Quality Function Deployment ( QFD ) akan dapat diketahui keinginan dan kebutuhan konsumen terhadap pelayanan kesehatan rumah sakit serta dapat diidentifikasikan pula respon teknis yang berhubungan dengan pemenuhan keinginan dan kebutuhan konsumen tersebut dalam rangka peningkatan kepuasan konsumen terhadap pelayanan kesehatan rumah sakit.
\end{abstract}

Kata Kunci : Tangible, Layanan, Quality Fuction Deployment ( QFD )

\section{PENDAHULUAN}

\section{Latar Belakang}

Rumah Sakit sebagai salah satu fasilitas pelayanan kesehatan memiliki peran yang sangat strategis dalam upaya mempercepat peningkatan derajat kesehatan masyarakat. Peran strategis ini didapat karena Rumah Sakit adalah fasilitas kesehatan yang padat teknologi dan padat pakar. Peran tersebut semakin menonjol mengingat timbulnya perubahan-perubahan epidemiologi penyakit, perubahan struktur demografis, perkembangan IPTEK, perubahan struktur sosio-ekonomi masyarakat dan pelayanan yang bermutu, ramah dan sanggup memenuhi kebutuhan mereka.

Rumah Sakit merupakan salah satu sistem produksi yang tidak menghasilkan produk berwujud ( tangible ) tetapi keluarannya berupa jasa ( layanan ). Masukan untuk suatu system produksi jasa seperti Rumah Sakit adalah konsumen itu sendiri. Proses produksi yang mengubah masukan menjadi keluaran terdiri dari tenaga kerja, teknologi, informasi dan sebagainya.

Dalam sistem jasa Rumah Sakit yang menjadi dasar dan ujung tombak pelayanannya kepada masyarakat adalah layanan pelanggan / customer service. Karena itu sistem pelayanan yang diberikan kepada pelanggan harus bisa diproses dengan cepat dan tepat. 
Rumah Sakit dituntut untuk memberi pelayanan yang bermutu sehingga dapat memuaskan konsumennya. Kepuasan konsumen didefinisikan sebagai sikap konsumen secara keseluruhan yang memandang dengan baik suatu barang atau jasa setelah memperoleh dan menggunakannya. Jadi kepuasan konsumen adalah penilaian setelah melakukan konsumsi.

Rumah Sakit perlu menetapkan strategi dan pemahaman sikap yang tepat karena sikap merupakan faktor psikologis yang dapat mempengaruhi konsumen dalam membuat keputusan dalam memilih Rumah sakit. Diharapkan supaya konsumen memiliki sikap yang baik terhadap Rumah Sakit. Sikap yang baik ini diiringi dengan keuntungan bagi Rumah Sakit, baik secara material ( laba) maupun non material (reputasi ).

Rumah sakit Umum daerah Kabupaten Gresik mempunyai prospek yang cukup baik dalam memberikan pelayanan kesehatan bagi masyarakat. Perkembangan penduduk kota Gresik yang semakin hari semakin padat akan sangat berperan pada pihak Rumah Sakit Umum daerah untuk bisa memberikan kualitas pelayanan kesehatan yang baik yang sangat dibutuhkan oleh masyarakat.

Sikap pengguna jasa pelayanan Rumah Sakit Umum Daerah saat ini semakin kritis dengan banyaknya tuntutan pelayanan yang mampu diberikan kepada konsumen. Konsumen sangat mengharapkan kepada pihak pengelola Rumah Sakit Umum Daerah untuk dapat meningkatkan kualitas pelayanannya. Pihak manajemen sebaiknya merencanakan sistem pelayanan yang sebaik mungkin guna merespon pengaduan dari masyarakat ( konsumen ). Pengaduan yang diterima pihak Rumah Sakit merupakan penilaian dari pelanggan tentang kualitas pelayanan yang selama ini mampu diberikan kepada konsumen.

\section{Perumusan Masalah}

Dari latar belakang yang ada maka dapat dirumuskan permasalahan sebagai berikut :

1. Atribut-atribut apa saja yang diinginkan konsumen terhadap kualitas pelayanan kesehatan rumah sakit.

2. Faktor - faktor apa saja yang berpengaruh terhadap kualitas pelayanan kesehatan rumah sakit

3. Atribut-atribut apa saja yang harus diprioritaskan perbaikannya untuk meningkatkan kualitas pelayanan kesehatan rumah sakit.

\section{Batasan Masalah}

Untuk membatasi permasalahan agar sesuai dengan tujuan penelitian maka ditetapkan batasan-batasan permasalahan sebagai berikut :

1. Dalam penelitian ini penulis tidak memasukkan atribut biaya dan tarif.

\section{Asumsi-Asumsi}

Dalam penyusunan penelitian ini menggunakan asumsi-asumsi untuk membantu dalam memecahkan permasalahan. Asumsi-asumsi yang digunakan sebagai berikut :

1. Dalam pengidentifikasian sampel penelitian, tingkat ketelitian dan keyakinan adalah $95 \%$, tingkat kesalahan adalah $5 \%$. 
5. Taraf signifikan untuk uji validitas sebesar $5 \%$.

\section{TINJAUAN PUSTAKA}

Quality Function Deployment. (QFD)

QFD pertama kali diterapkan di Mitsubishi, suatu perusahaan industri berat di Kota Kobe, Japan pada tahun 1972.

Di Amerika QFD dikembangkan oleh DR. Clausing dan diaplikasikan di industri manufaktur maupun dan menjadi standart pada kebanyakan organisasi. Contoh perusahaan yang menerapkan QFD antara lain DEC, Hawlett Packard, AT\&T, Ford, general Motor, dsb.

Menurut Cohen, ( 1995 ), QFD merupakan alat perencanaan yang digunakan untuk memenuhi harapan-harapan konsumen. Pendekatan disiplin QFD terletak pada desain produk, rekayasa, produktivitas serta memberikan evaluasi yang mendalam terhadap suatu produk. Suatu organisasi yang mengimplementasikan QFD secara tepat dapat meningkatkan pengetahuan rekayasa, produktivitas dan kualitas, mengurangi biaya, mengurangi waktu pengembangan produk serta perubahanperubahan rekayasa seiring dengan kemajuan jaman dan permintaan konsumen.

\section{Tujuan dan Manfaat QFD}

Tujuan QFD adalah memenuhi sebanyak mungkin harapan konsumen, dan berusaha melampaui harapan tersebut dengan merancang produk baru agar dapat berkompetisi dengan produk dari kompetitor untuk kepuasan konsumen.

QFD berguna untuk memastikan bahwa suatu perusahaan memusatkan perhatiannya terhadap kebutuhan konsumen sebelum setiap pekerjaan perancangan dilakukan.

Sedangkan manfaat-manfaat QFD adalah sebagai berikut :

- Memusatkan peancangan produk dan jasa pada kebutuhan dan kepuasan konsumen

- Menganalisa kinerja produk perusahaan untuk memenuhi kepuasan konsumen

- Mengurangi banyaknya perubahan desain

\section{Implementasi QFD}

Implementasi QFD secara garis besar dibagi dalam 3 (tiga) tahap, tetapi sebelum memasuki ketiga tahap tersebut selalu ada Tahap Perencanaan dan Persiapan.

Adapun ketiga tahap tersebut adalah :

1. Tahap pengumpulan Voice of Customer

2. Tahap penyusunan House of Quality

3. Tahap analisa dan interpretasi

\section{Definisi Jasa}

Philip Kotler ( 1994 ) mendefinisikan dari suatu yang dinamakan jasa adalah setiap kegiatan atau manfaat yang ditawarkan oleh suatu pihak pada pihak lainnya 
dan pada dasarnya tidak berwujud, serta tidak menghasilkan kepemilikan sesuatu. Jasa sebagai bagian dari suatu keluaran selain barang seringkali mengalami bauran dengan produk berupa barang yang bervariasi, sehinga kadangkala terjadi kesulitan pembedaannya kecuali jika kita telah mendefinisikan perbedaanya lebih lanjut.

Jasa memiliki beberapa karakteristik sebagai berikut:

1. Tidak berwujud ( intangibility )

Karena jasa memiliki sifat tidak nyata, maka tidaklah mungkin bagi pelanggan untuk merasakan jasa sebelum mereka membelinya. Sifat jasa ini memberikan tekanan pada organisasi pemasaran. Tekanan terjadi terutama pada program promosi perusahaan. Departemen periklanan harus memusatkan perhatiannya pada manfaat yang didapatkan dari jasa, dibandingkan penekanan pada jasa itu sendiri. Dari pengertian ini maka tugas seorang pemberi jasa adalah mengelola keterangan atau informasi untuk mewujudkan program yang tidak berwujud.

2. Tidak dapat dipisahkan ( inseperability )

Jasa pada umumnya dihasilkan dan dikonsumsi pada saat yang sama. Anggapan bahwa barang fisik dapat diproduksi, ditempatkan di gidang, dijual lalu kemudian dikonsumsi adalah salah. Bila jasa ini disambungkan oleh seseorang maka dia akan menjadi bagian dari jasa tersebut, dimana interaksi antara pemberi jasa dan pelanggan adalah ciri khusus dari pemasaran jasa. Dari pengertian diatas dapat diambil benah merah, dimana jasa sering tidak dapat dipisahkan dari penjualnya. Hal ini dipahami bahwa penjualan langsung adalah satu-satunya cara pendistribusian dan jasa tidak dapat dijual dibanyak tempat. Sifat inilah yang juga membatasi skala operasi perusahaan jasa.

3. Keragaman ( heterogenity )

Tidaklah mungkin suatu industri jasa untuk mengadakan standarisasi hasil atau outputnya. Setiap unit jasa akan tidak sama dengan unit jasa yang lain meskipun dari jasa yang sama. Hal ini yang menyulitkan adalah menilai kualitas jasa, maupun meramalkan kualitas jasa yang akan diterima. Tetapi dari berbagai kesulitan tersebut dapat dilakukan pengendalian kualitas.

4. Keadaan yang tidak tahan lama ( perishability ) dan permintaan yang tidak stabil.

Jasa sangat bersifat tidak tahan lama dan tidak dapat disimpan. Energi listrik yang tidak terpakai, kursi kosong dipesawat terbang dan mekanik yang menganggur merupakan suatu contoh bisnis yang hilang selamanya. Lebih jauh lagi pasar jasa, pasar jasa berfluktuasi tergantung dari musim, hari-hari tertentu dalam seminggu, atau pada jam-jam tertentu. Terdapat beberapa pengecualian pada penyamaan jasa sehubungan dengan sifat tidak tahan lama dan tidak dapat disimpan. Contohnya pada asuransi jiwa dan kesehatan, jasa dibeli, kemudian disimpan oleh penjual sampai diperlukan pembelian.

\section{Konsep Tentang Mutu}

Mutu adalah salah satu pokok masalah yang sering disalah pahami dalam bisnis sekarang ini, walaupun merupakan inti kelangsungan hidup organisasi yang 
paling besar. Mutuditentukan oleh pelanggan, pertama-tama kita mengetahui apa kebutuhan pelanggan, kemudian memproduksi tepat seperti apa yang dikehendaki pelanggan dalam jangka waktu yang disetujui dengan biaya serendah mungkin. Hanya bisnis yang memusatkan perhatian pada pelanggan, pelangganlah yang akan dapat menjaga kelangsungan hidup sampai masa depan. Maka mutulah mungkin merupakan cara yang paling baik untuk memastikan adanya kesetiaan pelanggan, pertahanan yang baik terhadap pesaing dan satu-satunya jalan untuk memantapkan pertumbuhan dan keuntungan yang berkesinambungan dalam keadaan pasar yang sulit.

Menurut Zeithaml, Parasuraman dan Berry ( 1990 ), kualitas jasa didefinisikan sebagai pemenuhan bahkan melebihi keinginan dan harapan pelanggan. Jasa dapat diartikan sebagai proses pelayanan yang diberikan oleh produsen kepada konsumen.

Dimensi untuk mengukur kualitas jasa ada 10, yaitu:

1. Tangible

Penampilan fasilitas fisik, personil dan material komunikasi.

2. Reliability

Kemampuan untuk menghasilkan kinerja pelayanan yang sudah dijanjikan secara akurat dan pasti.

3. Responsiveness

Ketanggapan terhadap kebutuhan pelanggan, jika mau membantu dan memberikan pelayanan terbaik.

4. Competence

Keahlian, keterampilan dan kemampuan yang dimiliki sehingga dapat memberikan layanan yang baik.

5. Courtesy

Sikap yang sopan, ramah, hormat dan perhatian saat memberikan pelayanan.

6. Credibility

Kepercayaan pelanggan terhadap pelayanan yang diberikan.

7. Security

Bebas dari rasa takut, bahaya, ragu-ragu terhadap pelayanan yang diberikan.

8. Acces

Kemudahan untuk dicapai dan dihubungi.

9. Communication

Memberikan informasi kepada konsumen secara jelas dengan bahasa yang mudah dimengerti.

10. Understanding the customer

Berusaha mengerti apa yang diharapkan dan diinginkan oleh pelanggan.

Kenyataannya terdapat tumpang tindih diantara dimensi-dimensi tersebut, sehingga dikelompokkan menjadi lima komponen utama untuk mengukur kualitas jasa yang disebut sebagai model servqual, yaitu:

1. Tangible

Berkaitan dengan fasilitas fisik, peralatan, personil, dan matrial komunikasi.

2. Reliability 
Kemampuan untuk menghasilkan kinerja pelayanan yang sudah dijanjikan secara akurat dan pasti kepada pelanggan.

3. Responsiveness

Ketanggapan terhadap kebutuhan pelanggan, sikap mau membantu dan memberikan pelayanan terbaik.

4. Assurance

Berkaitan dengan pengetahuan, kesopanan, dan kemampuan personil untuk menimbulkan rasa kepercayaan, keamanan dan keyakinan bagi pelanggan.

5. Emphaty

Sikap perhatian, peduli dan berusaha mengetahui keinginan pelanggan.

\section{HASIL DAN PEMBAHASAN}

Pengumpulan Data

Data penelitian dikumpulkan dengan jalan wawancara yang dilanjutkan dengan penyebaran kuisioner ke responden yang pernah mendapatkan pelayanan kesehatan di RSUD Bunder Kabupaten Gresik.

\section{Pengolahan Data}

Pada tahap ini dilakukan pengolahan data untuk Quality Function Deployment (QFD). Penerapan QFD ini dapat dilakukan dengan menggunakan matriks yang disebut Rumah Kualitas atau House of Quality (HOQ). Adapun tahaptahap pembentukan rumah kualitas adalah sebagai berikut:

\section{Voice Of Customer ( VOC )}

Pengumpulan suara pelanggan ( VOC ) ini dilakukan dengan wawancara langsung dan penyebaran kuisioner ke konsumen yang menjadi sampel dalam penelitian.

Voice of customer ini merupakan keinginan dan harapan yang diinginkan oleh konsumen terhadap kualitas pelayanan kesehatan rumah sakit.

Dari hasil wawancara langsung dan penyebaran kuisioner dengan responden dijumpai bahwa keinginan dan harapan mereka sangat beragam. Dari keinginan dan harapan yang beragam tadi dapat dikumpulkan menjadi sekumpulan voice of customer yang mencerminkan keinginan dan harapan responden.

Berdasarkan data customer needs yang diperoleh, kemudian dibuat pengelompokan atribut berdasarkan sifatnya seperti pada tabel 1 .

Tabel 1. Pengelompokan atribut berdasarkan sifatnya

\begin{tabular}{|l|l|}
\hline \multicolumn{2}{|c|}{ Customer Requirements (WHATs) } \\
\hline Tangible & Kelengkapan peralatan medik \\
\cline { 2 - 2 } & Keberfungsian peralatan medik \\
\cline { 2 - 2 } & $\begin{array}{l}\text { Kelengkapan fasilitas pelayanan kesehatan ( poli,UGD,Lab.,Apotek, } \\
\text { ambulance,dll ) }\end{array}$ \\
\cline { 2 - 2 } & Kelengkapan obat-obatan yang tersedia \\
\cline { 2 - 2 } & Mudah dijangkau dengan kendaraan \\
\hline Reliable & Ketenangan suasanan rumah sakit \\
\cline { 2 - 2 } & Keamanan rumah sakit \\
\cline { 2 - 2 } & Kebersihan lingkungan rumah sakit \\
\hline
\end{tabular}




\begin{tabular}{|c|c|}
\hline & Kerapihan dan kebersiham staf medik maupun non medik \\
\hline \multirow[t]{5}{*}{ Responsiveness } & Kesabaran dan ketelatenan dokter dan perawat \\
\hline & Keramahan staf medik,perawat, dan non medik \\
\hline & Kemudahan prosedur administrasi \\
\hline & Adanya jadwal kunjungan dokter yang rutin \\
\hline & Kecepatan dokter dan perawat dalam menangani pasien \\
\hline \multirow[t]{3}{*}{ Assurance } & $\begin{array}{l}\text { Kemampuan dokter dan perawat memberikan pelayanan dan } \\
\text { pengobatan }\end{array}$ \\
\hline & Reputasi dan jam terbang dokter \\
\hline & Reputasi dan nama baik rumah sakit di mata pelanggan \\
\hline \multirow[t]{2}{*}{ Emphaty } & Setiap keluhan diterima dengan baik \\
\hline & $\begin{array}{l}\text { Adanya komunikasi yang baik antara pihak rumah sakit dengan } \\
\text { pelanggan }\end{array}$ \\
\hline
\end{tabular}

\section{Matriks Perencanaan (Planning Matrixs)}

Matriks perencanaan ini terdiri dari :

\section{a. Importance to Customer}

Bagian ini berisikan hal-hal yang dipentingkan oleh konsumen terhadap pelayanan kesehatan rumah sakit.

\section{b. Customer Satisfaction Performance}

Customer Satisfaction Performance adalah persepsi konsumen mengenai seberapa baik produk / pelayanan ( jasa ).

\section{c. Goal}

Goal merupakan level performansi yang ingin dicapai perusahaan untuk memenuhi customer need. Goal dinyatakan dalam bentuk skala numerik yang sama dengan tingkat performansi. Nilai goal untuk semua atribut dalam penelitian ini ditetapkan 5. Ini berdasarkan hasil tingkat kepuasan konsumen yang dipeoleh berada pada skala 3 dan 4, dan pihak pengelola menginginkan adanya peningkatan kualitas pelayanan kesehatan yang ada.

\section{d. Improvement Ratio}

Improvement Ratio merupakan suatu nilai yang menunjukkan seberapa besar peningkatan layanan yang harus dilakukan perusahaan untuk memenuhi keinginan konsumen. Nilai ini diperoleh dari hasil bagi antara Goal dengan Current Customer satisfaction. Formulasi dalam menentukan Improvement Ratio adalah dengan cara membagi Goal dengan Current Satisfaction Performance.

Improvement ratio=goal $/$ cust.satisf. perform.

\section{e. Sales Point}

Sales Point merupakan informasi mengenai kemampuan menjual produk atau jasa (pelayanan) berdasarkan seberapa baik setiap customer need terpenuhi. Nilai untuk sales point adalah :

1 : tidak ada titik penjualan

1.2 : titik penjualan menengah

1,5 : titik penjualan kuat 
Nilai Sales Point ditentukan berdasarkan Importance to Customer. Atribut yang paling dipentingkan oleh konsumen akan memiliki nilai Sales Point tertinggi.

\section{f. Raw Weight}

Kolom ini berisi nilai perhitungan dari data dan keputusan yang dibuat selama matriks perencanaan. Raw weight memodelkan kepentingan keseluruhan bagi tim dari tiap customer need, berdasarkan importance to customer, improvement ratio, dan sales point. Nilai dari Raw weight untuk tiap customer need adalah :

Raw weight $=($ Importance to Customer $) \times($ improvement ratio $) \times$ (sales point $)$

\section{g. Normalized Raw Weight}

Kolom ini berisi nilai raw weight, yang diskalakan pada kisaran antara $0-1$ atau dalam persen.

Normalized raw weight dirumuskan sebagai berikut :

Normalized Raw Weight $=$ Raw Weight $/$ Raw Weight Total

\section{Substitute Quality Characteristics (SQC) / Respon Teknis}

Respon teknis merupakan kemampuan teknis yang dimiliki oleh perusahaan untuk memenuhi Customer Need.

Dalam penelitian ini respon teknis yang dimunculkan dari pihak pengelola dapat dilihat pada tabel 2 .

Tabel 2.Respon Teknis

\begin{tabular}{|c|l|}
\hline No & \multicolumn{1}{|c|}{ Respon Teknis } \\
\hline 1 & Peningk. pengelolaan sarana \\
\hline 2 & Peningk. pengelolaan lingk. \\
\hline 3 & Penyediaan obat-obatan yg lengkap \\
\hline 4 & Pel. SDM unt sikap \& perilaku \\
\hline 5 & Pendd.\&Pel.dokter\&perawat unt meningk.skill \\
\hline 6 & Sosialisasi prosedur pelayanan \\
\hline 7 & Jadual dokter jaga \\
\hline 8 & Proses rekruitment dokter \\
\hline 9 & Proses peningk. status rumah sakit \\
\hline 10 & Adanya customer service \\
\hline
\end{tabular}

Matriks Hubungan (Relationship Matrix) antara SQC dengan Customer Needs Matriks hubungan ini akan memperlihatkan hubungan atau sejauh mana pengaruh respon teknis (SQC) yang diberikan oleh sistem pelayanan dalam memenuhi kebutuhan pelanggan. Sel-sel yang menggambarkan hubungan tersebut akan diisi dengan simbol yang menggambarkan sejauh mana hubungannya.

\section{Korelasi Teknis (Technical Correlations)}

Technical Correlation digunakan untuk mengidentifikasi hubungan antara masing-masing respon teknis. 


\section{Matrik Teknis}

Matrik teknis terdiri dari :

\section{a. Prioritas}

Merupakan nilai yang menunjukkan kontribusi dari respon teknis terhadap pemenuhan keinginan konsumen yang ada.

\section{Priorities $=\Sigma($ Normalized Raw Weight $\mathbf{x}$ Nilai Numerik Relationship Matriks)}

\section{b. Performance}

Cara menghitung performance sebagai berikut:

Own PerformanceRi $=\sum$ (cust.satisf.perform. $x$ numeric val. $) / \sum$ numeric val.

Dimana $\mathrm{Ri}=$ respon teknis ke-i

Secara lengkap gambar house of quality dapat dilihat pada gambar 1.

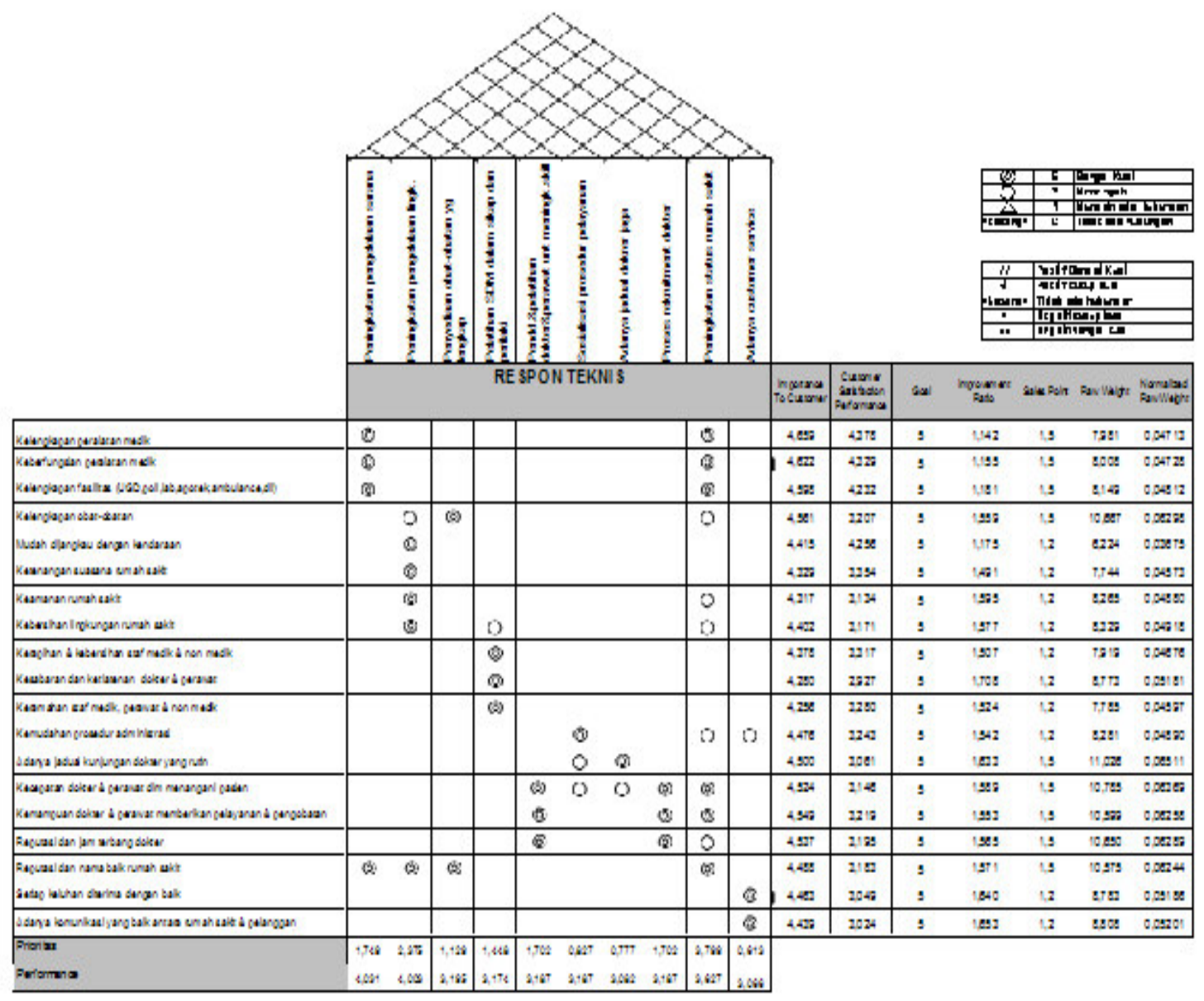

Gambar 1. House Of Quality 


\section{ANALISIS DAN INTERPRETASI}

\section{Analisis Prioritas Keinginan User}

Planning matrix dari rumah kualitas terdapat prioritas keinginan konsumen yang berisi nilai-nilai yang menentukan atribut keinginan apa yang paling diprioritaskan oleh konsumen

Dapat dikatakan bahwa semakin tinggi nilai tingkat kepentingan dari suatu atribut maka akan menunjukkan atribut tersebut semakin dipentingkan oleh konsumen dalam hubungannya dengan pelayanan kesehatan rumah sakit, sehingga pengelola rumah sakit harus memperhatikan keberadaan atribut yang mempunyai nilai kepentingan tertinggi pada pelayanan kesehatan rumah sakit.

Sedangkan untuk mengetahui prioritas keinginan konsumen terhadap pelayanan kesehatan rumah sakit di RSUD Bunder kabupaten Gresik dapat dilihat dari besarnya nilai raw weight dari setiap atribut.

Dapat dikatakan bahwa semakin tinggi nilai raw weight dari suatu atribut maka akan menunjukkan atribut tersebut semakin diinginkan oleh konsumen dalam hubungannya dengan peningkatan kualitas pelayanan kesehatan di RSUD Bunder Kabupaten Gresik, sehingga pengelola rumah sakit harus memperbaiki kualitas pelayanan kesehatan berdasarkan atribut yang mempunyai nilai raw weight tinggi untuk meningkatkan kepuasan konsumen.

\section{Analisis Respon Teknis}

Respon teknis adalah hal - hal teknis yang mempunyai pengaruh dalam perbaikan kualitas yang berhubungan dengan apa yang diinginkan konsumen. Analisis respon teknis meliputi kontribusi prioritas dan performansi dari respon teknis.

Kontribusi prioritas respon teknis menunjukkan seberapa besar suatu respon teknis mempunyai pengaruh terhadap kualitas pelayanan kesehatan RSUD Bunder Kabupaten Gresik.

Berdasarkan nilai dari prioritas respon teknis maka dapat dikatakan bahwa atribut yang mempunyai nilai kontribusi terbesar adalah atribut yang paling berpengaruh dalam memperbaiki kualitas pelayanan kesehatan RSUD Kabupaten Gresik.

\section{KESIMPULAN DAN SARAN}

\section{Kesimpulan}

1. Atribut-atribut yang diinginkan konsumen dalam hal pelayanan kesehatan rumah sakit adalah: kelengkapan peralatan medik, keberfungsian peralatan medik, kelengkapan fasilitas pelayanan kesehatan ( poli, UGD, lab.,apotik, ambulance, dll ), kelengkapan obat-obatan yang tersedia, mudah dijangkau dengan kendaraan, ketenangan suasana rumah sakit, keamanan rumah sakit, kebersihan lingkungan rumah sakit, kerapihan dan kebersihan staf medik maupun non medik, kesabaran dan ketlatenan dokter dan perawat, keramahan staf medik dan non medik, kemudahan prosedur administrasi, adanya jadual kunjungan dokter yang rutin, kecepatan dokter dan perawat dalam menangani pasien, kemampuan dokter dan perawat memberikan pelayanan dan pengobatan, reputasi dan jam terbang dokter, reputasi dan nama baik rumah sakit di mata konsumen, setiap keluhan diterima 
dengan baik, adanya komunikasi yang baik antara pihak rumah sakit dengan konsumen.

2. Respon teknis yang perlu dipersiapkan dalam rangka pemenuhan keinginan konsumen dalam pelayanan kesehatan rumah sakit adalah: peningkatan pengelolaan sarana, peningkatan pengelolaan lingkungan, penyediaan obat-obatan yang lengkap, pelatihan SDM dalam sikap dan perilaku, pendidikan dan pelatihan dokter dan perawat untuk meningkatkan skill, sosialisasi prosedur administrasi, adanya jadual dokter jaga, proses rekruitmen dokter, peningkatan status rumah sakit, adanya customer services.

3.Untuk meningkatkan kualitas pelayanan kesehatan rumah sakit harap diperhatikan atribut-atribut yang masih mempunyai nilai tingkat kepuasan yang rendah.

\section{Saran-saran}

1.Usulan yang berhubungan dengan peningkatan kualitas pelayanan.

Dalam peningkatan kualitas pelayanan kesehatan rumah sakit, maka atribut-atribut yang berhubungan langsung dengan proses pelayanan kepada konsumen harus

ditingkatkan karena atribut-atribut tersebut memiliki kontribusi terbesar terhadap kebutuhan dan keinginan konsumen.

2. Usulan yang berhubungan dengan pengembangan penelitian.

Memperdalam ruang lingkup penelitian yang diteruskan dengan penelitian lanjutan mengenai kualitas pelayanan di masing-masing unit yang ada.

\section{DAFTAR PUSTAKA}

Cohen L, "Quality Function Deployment : How To Make Quality Function Deployment Work for You“, Addison Wesley Publishing Company Massachuset, 1995.

Date Besterfield, "Total Quality Management", Prentice Hall, Engelwood Cliff new Jersey, 1995.

Kotler dan Amstrong, 2000, "Prinsip-Prinsip Pemasaran", Edisi Kedelapan, Erlangga, Jakarta.

Kotler, Philip, 1997, "Manajemen Pemasaran, Analisis, Perencanaan, Implementasi, dan Kontrol", Edisi Bahasa Indonesia, Prentice Hall, Jakarta.

Kotler, Philip., Susanto, AB, 2001, "Manajemen Pemasaran di Indonesia”, Salemba Empat, Jakarta.

Parasuraman A, Valery A, Zeithhalm dan Leonardo L, Berry, "Delivering Quality Service Balancing Customer Perception dan Expectation“, The Free Press, New York, 1990.

Rambat Lupiyoadi, "Manajemen Pemasaran Jasa“, Jakarta, 2000 